\title{
An analysis of the relative performance of Japanese and foreign money management
}

\author{
Stephen J. Brown, NYU Stern School of Business \\ William N. Goetzmann, Yale School of Management \\ Takato Hiraki, International University of Japan, Graduate School of International \\ Management \\ Noriyoshi Shiraishi, Rikkyo University
}

First draft January 18, 2001

Current draft September 25, 2002

\begin{abstract}
Foreign investment management firms have recently started to play a major role in the investment trust business in Japan. In terms of assets under management, their size and market share have almost doubled in the past several years. In part, the relative success of foreign managed firms in attracting market share may be attributed to the fact that Japanese investment trusts have underperformed benchmarks in quite a dramatic fashion over the past two decades. This is at best indirect evidence that Japanese funds underperform their foreign counterparts. In a recent paper (Brown, Goetzmann, Hiraki, Otsuki and Shiraishi 2001) we show that the underperformance can be attributed almost entirely to the unique tax environment of Japanese investment trusts, which had the effect of heavily penalizing early withdrawals. The relaxation of these regulations coincided with a major inflow of new money into the investment trust business. We examine the relative performance of Japanese and foreign investment management firms before and after this change in tax regulations, and find that the poor relative performance of Japanese funds from April 2000 through December 2001 may in part be attributed to the huge inflow of new money into this sector and the style shifts made necessary to accommodate this flow.
\end{abstract}




\title{
An analysis of the relative performance of Japanese and foreign money management
}

Current draft September 25, 2002

\begin{abstract}
Foreign investment management firms have recently started to play a major role in the investment trust business in Japan. In terms of assets under management, their size and market share have almost doubled in the past several years. In part, the relative success of foreign managed firms in attracting market share may be attributed to the fact that Japanese investment trusts have underperformed benchmarks in quite a dramatic fashion over the past two decades. This is at best indirect evidence that Japanese funds underperform their foreign counterparts. In a recent paper (Brown, Goetzmann, Hiraki, Otsuki and Shiraishi 2001) we show that the underperformance can be attributed almost entirely to the unique tax environment of Japanese investment trusts, which had the effect of heavily penalizing early withdrawals. The relaxation of these regulations coincided with a major inflow of new money into the investment trust business. We examine the relative performance of Japanese and foreign investment management firms before and after this change in tax regulations, and find that the poor relative performance of Japanese funds from April 2000 through December 2001 may in part be attributed to the huge inflow of new money into this sector and the style shifts made necessary to accommodate this flow.
\end{abstract}

\section{Introduction}

The investment trust business in Japan has grown very substantially over the last few years. Assets of open-type equity funds grew 82 percent from January 1998 to their maximum value of $¥ 164$ Trillion on May 2, 2000, falling to $¥ 143$ Trillion by the end of 2001, a net increase of 58 percent over the entire period. In the period from January 1998 to January 2000 alone assets of open-type equity funds grew by 61 per cent. As indicated in Figure 1, a large part of that increase can be attributed to the increase in assets under management by foreign owned investment trusts. As illustrated in Figures 2, 3 and 4, foreign investment management firms have recently started to play a major 
role in the investment trust business in Japan. Over the period from 1998 to 2000 their market share almost doubled ${ }^{1}$, with more than 71 per cent of this growth coming from net inflow of funds, particularly in 1998 (Figure 5). Most of this increase in market share can no doubt be traced to aggressive marketing by foreign owned firms. The success of this marketing effort is evident in Figures 3 and 4 which show how many new foreign firms have entered the market. Fidelity in particular has very quickly obtained a significant market share. This market share has come at the expense of traditional firms like Nomura and Daiwa. Another reason for the increase in foreign market share is the purchase by foreigners of traditional Japanese asset managers ${ }^{2}$. However, at least part of this increased market share can be attributed to the fact that Japanese investment trusts have underperformed benchmarks in quite a dramatic fashion over the past two decades ${ }^{3}$.

${ }^{1}$ From January 23, 1998 to December 28, 2001 the number of foreign managed trusts grew from 184 to 490 , including 28 funds jointly owned by Japanese and foreign interests. The market share of foreign managed funds also increased from $16.8 \%$ of assets under management in 1998 to $25.7 \%$ by the end of 2001 .

${ }^{2}$ Merrill’s investment trust business grew from $¥ 1.31$ Billion to $¥ 4.40$ Billion in assets under management from 1998 to 2000 with the acquisition of Yamaichi's franchise. However, their asset management affiliate, Yamaichi Asset Management was purchased by Société Générale and is starting to attain significant market share as SG Yamaichi Asset Management.

${ }^{3}$ This underperformance was documented in Cai, Chan and Yamada (1997). These authors were careful in the way they explained their findings. However journalists were quick to attribute this poor relative performance to mismanagement by Japanese investment trust managers with articles such as "Japanese investment trusts: Punting in the dark" (Economist January 22, 1994). 
This widely publicized fact has shaken public confidence in the industry, the third largest investment trust business in the world outside of the United States and France. There is a widespread perception that foreign managers are simply more skillful than their Japanese competition. ${ }^{4}$ Kamesaka, Nofsinger, and Kawakita (2002) document that foreign traders in the Japanese equity market were able to profit from their trading activities there as the market fell through the 1990's. Some have argued, for example, that it is difficult for Japanese investors to compete with foreign traders who can exploit opportunities that arise from institutional differences between local and home markets. ${ }^{5}$ On the other hand, foreign owned investment trusts operate in the same markets, are subject to the same regulatory environment, and employ large numbers of Japanese and Japanese trained managers. It would be strange indeed to find that foreign investors could systematically overcome the informational advantage of their domestic competition. In fact, a close analysis of the data for Korea and elsewhere confirms that domestic traders do well in small or illiquid investments where we would expect the informational asymmetry to be most severe (Kim (2002)). Foreign investors were quicker to react to the downturn in the markets in Japan in 1990 than were the

${ }^{4}$ This view is common in other Asian countries. Kim (2002) observes that the widespread view that foreigners are simply more skillful than domestic investors leads many in Korea and elsewhere to adopt "follow the foreigner" investment strategies.

${ }^{5} \mathrm{Bae}$, Ito and Yamada (2001) show that there is empirical evidence that foreign traders not governed by Japanese corporate accounting rules can take advantage of limited trading opportunities of local investors. It is not clear that this attribute is shared by foreign owned institutions operating within Japan and subject to Japanese law and regulations, competing against domestically owned investment trusts. 
domestic investors (Kamesaka, Nofsinger, and Kawakita (2002)), but this does not necessarily speak to their longer term superiority, and may suggest instead that they typically follow naive trend-following strategies.

The fact that Japanese investment trusts underperform established benchmarks does not necessarily show that Japanese funds underperform their foreign counterparts. In a recent paper (Brown, Goetzmann, Hiraki, Otsuki and Shiraishi 2001 ) (BGHOS) we show that the reported underperformance can be attributed almost entirely to the unique tax environment of Japanese investment trusts. In 1966 tax regulations were introduced that had the effect of heavily penalizing early withdrawals from investment trusts $^{6}$. It is fair to say that these regulations significantly inhibited the growth of the investment trust industry. In March 1998 the Japanese Cabinet recommended for legislation "The Three-Year Implementation Plan on Public Administrative Deregulations," which included a revision of investment trust tax treatment to conform with international standards, to come into effect on April 1, 20007. In addition to revising the tax treatment of investment trusts, this legislation allowed investment trusts to incorporate in a manner similar to US mutual funds. The relaxation of these

${ }^{6}$ Both Cai, Chan and Yamada (1997) and Brown, Goetzmann, Hiraki, Otsuki, and Shiraishi (2001) document the features of this adverse tax regime.

${ }^{7}$ Initially, this regulatory change was to go into effect for all investment trusts. However, bond funds were given an additional year to comply with the new regulations due to the perceived complexity of introducing market value-based accounting standards for many low liquidity unlisted corporate bonds. 
regulations coincided with a major inflow of new money into Japanese managed investment trusts, amounting to $¥ 27.7$ Trillion from January to December 2000. This amount represents 26.3 percent of the assets of Japanese investment trusts as of the beginning of the year. Unfortunately, a very large majority of this new money (91.7 percent) flowed into Japanese general equity accounts which peaked in value coincidently with the change in tax regulations, and subsequently lost 25 percent in value on an annualized basis up to December 28, 2001.

The increased market share of foreign investment management firms in Japan from 1998 to the present allows a direct test of the hypothesis of foreign superiority in the investment management business. Foreign investment trusts have taken a significant market share of the Japanese investment trust industry in the last four years. For this reason, it is possible to analyze their relative performance in the same investment environment by analyzing week by week returns. Contrary to popular perception Japanese managers did not underperform their foreign competition in the period of our data from January 23, 1998 through December 28, 2001. While Japanese investment trusts ended up with a loss of 5 percent over the entire period, this loss was indistinguishably different from the annualized value weighted geometric return of negative 4.3 percent experienced by foreign managers over the same period (Figure 6). We will find the same pattern of returns even after controlling for sector allocations by Japanese investors outside the control of Japanese managers. However, in no case are 
the returns significantly different from foreign managers, after controlling for style of management. The evidence suggests that Japanese managers happened to be in the right place at the right time as the market rose. But then, victims of their own success, they were burdened with massive fund inflows just as the markets were turning against them.

The paper is organized as follows. Section II describes the data and methodology used in our analysis. Section III reports the results. The conclusion discusses the implications of our findings and directions for future research.

\section{Data and Methodology}

\section{II.1 Data}

The data used in our study derives from a database of daily fund valuations provided by QUICK Corporation for 3072 open-type funds from January 23, 1998 through December 28, 2001. Total fund values are given as well as net asset value per share (NAV). From this data are constructed 205 weekly holding period rates of return. Returns are computed using NAV computed at the end of each week as well as dividends paid during that week, per unit of the investment trust contract. QUICK Corp. also provided the thirty-two narrowly classified Investment Trust Association (ITA) categories. As in BGHOS (2001) we use this data to construct 11 broader classifications separately 
breaking out Bull and Bear derivative funds using the Monthly Report for December 2001 issued by Kinyu Data Systems (KDS), which is basically the same as the one used by the ITA. For the purpose of benchmark comparison we use a money market rate based on the end of week percentage return quoted for three month Japanese CD's, a Japanese domestic fixed income return given as the percentage weekly change in the JP Morgan Japanese Government Bond Index (denominated in Yen), a Japanese domestic equity return given as the percentage weekly change in TOPIX index, and finally a foreign equity return given as the percentage change in the end of week MSCI World Equity Index excluding Japan converted into Japanese yen.

\section{II.2 Methodology}

Following BGHOS (2001) two distinct methods of analysis were used to study the performance attributes of investment trusts currently operating in Japan. In the first place we use a returns-based classification algorithm developed in Brown and Goetzmann (1997) [BG] to group the Japanese funds in our sample into a few parsimonious categories. This procedure is referred to as "Generalized Style Classification" (GSC). The objective of this procedure is to use past returns to determine a natural grouping of funds that has some predictive power in explaining the future cross-sectional dispersion in fund returns. If there are $\mathrm{K}$ such styles the ex post total return in period $t$ for any fund $j$ can be represented as:

$$
R_{j t}=\mu_{J t}+\varepsilon_{j t}
$$


where $\mu_{J t}$ is the expected return for style $\mathrm{J}$ conditional upon the factor realization $I_{t}^{8}$. If the idiosyncratic return component $\varepsilon_{j t}$ has zero mean ex ante and is uncorrelated across securities, the classification into styles will suffice to explain the cross-sectional dispersion of fund returns to the extent that $\mu_{J t}$ differs across styles. The algorithm used in BG assigns funds to styles in such a way as to maximize the explanatory power of this equation, allowing for time-varying and fund-specific residual return variance. As explained in BGHOS (2001) this procedure accounts for tax dilution effects to the extent that the tax dilution effect is common across funds in a particular style and hence impounded in $\mu_{J t}$. Note that this approach also justifies the common procedure of forming style benchmarks for performance evaluation by value-weighting returns within each style category ${ }^{9}$.

Once funds are allocated to styles, it is possible to determine the source of returns by examining the relationship between style benchmark returns $\hat{\mu}_{J t}$ and proxies for factor

${ }^{8}$ Observe that $l_{j t}=\mu_{J t}+\varepsilon$ is equivalent to ${ }_{j t}=\alpha_{J t}+\beta_{J t} I_{t}+\varepsilon \quad$ where $I_{t}=\alpha_{J t}+\beta_{J t} \quad$ allowing for time varying expected return and beta that are conditional on multivariate factor realizations $I_{t}$.

${ }^{9}$ To see this, note that the style benchmark $\hat{\mu}_{J t}$ given as the value-weighted average return within each style category, $\hat{\mu}_{J t}=\underset{j \in J}{\Sigma} w_{j t} R_{j t}$, is an unbiased estimator of the true
expected return conditional on the factor realizations as of date t: $\mathbf{E}\left(\hat{\mu}_{J t}-\mu_{J t}\right)=\mathbf{E}\left(\underset{j \in J}{\Sigma} w_{j t} \varepsilon_{j t}\right)=0$. 
realizations $I_{t}$. This regression corresponds to a procedure developed in Sharpe (1992), and recently applied to mutual funds (Brown and Goetzmann, 1997) and hedge funds (Fung and Hsieh, 1997). In this method, passive indices are used in a multi-factor linear model as benchmarks. The model constrains weights on these passive indices to be positive and sum to one, while also allowing an unconstrained intercept.

$$
R_{J t}=a_{J t}+\sum_{k=1}^{K} b_{J k} I_{k t}+\varepsilon_{J t}
$$

s.t.

$$
\begin{aligned}
\sum_{k=1}^{K} b_{J k} & =1 \\
b_{J k} & \geq 0 \forall k
\end{aligned}
$$

We can then infer time-varying expected return and sensitivity of the benchmark to factors using $\hat{\alpha}_{J t}=\underset{j \in J}{\sum} w_{j t} \hat{a}_{j}$ and $\hat{\beta}_{J t}=\underset{j \in J}{\Sigma} w_{j t} \hat{b}_{j}$.

Although we do not replicate the "conditional" performance measurement procedures (c.f. Ferson and Schadt, 1996), we do allow for time-varying exposure to factors both by allowing the value weights $w_{j t}$ to change and by estimating the model using only 12 weeks of data. However, since implied sensitivity is assumed constant over three months, this technology may not credit managers with timing skill. For this reason, the use of style benchmarks is preferable to this regression-based approach to performance 
measurement.

III. Results

Contrary to popular perception, Japanese funds significantly outperformed their foreign competition over the period from 1998 through the first quarter of 2001, but since then their performance has been disappointing. The relative performance of Japanese and foreign funds is presented in Figure 6, with the Japanese firms earning an annualized total return of negative 5 percent over the entire period from January 23, 1998 through December 28, 2001, indistinguishably different from the negative 4.3 percent for foreign firms over the same period.

As noted before much of the difference in returns between Japanese and foreign funds can be attributed to the pattern of funding by Japanese investors, leading to a significant overweighting in the General Equity sector, which did particularly poorly in the period post March 31, 2000. While most of the investment in Japanese investment trusts represented new money, examination of the pattern of return/flow correlations reveals that at least part of the investment in the General Equity sector prior to March 31, 2001 came at the expense of investments in Balanced Funds during this period (Table 1). However, post March 31, 2000, flows appear more to be driven by contemporaneous returns, consistent with herding in the Japanese markets. Indeed, the pattern of return/flow correlations before and after March 31, 2000 suggest a significant 
change in investor behavior before and after this date $\mathrm{e}^{10}$

To examine in some greater depth the differences between Japanese and foreign owned funds, we examined the time-varying sensitivity of Japanese funds and foreign funds to four asset classes found to be useful benchmarks of Japanese fund investment performance in BGHOS (2001). To do this we regressed fund returns on these four asset class returns constraining the sum to equal one, allowing for a constant term. Japanese and foreign implied asset weights were obtained as a weighted average of individual fund coefficients, where the weights were based on the asset value of each fund. These weights were computed on the basis of rolling six week intervals of the data, and the results plotted as Figures 7 and 8. Inspection of these Figures reveals that there are distinct differences between Japanese and foreign funds. The Japanese implied asset allocation is reasonably stable over the entire time period. A little more than 60 percent of Japanese funds are invested in Japanese domestic equity, with the remaining shares

\footnotetext{
${ }^{10}$ Prior to March 31, 2000, the correlation between flows to Japanese General Equity accounts was negatively correlated to flows into Japanese Balanced funds $(-0.2364)$ and foreign Balanced funds (-0.3404) significant at the five and one percent levels respectively. The correlation between foreign General Equity and Balanced fund flows is even more pronounced (correlation -.5391). Subsequent to March 31, these correlations decreased (only the Japanese General Equity flows have a significant negative correlation. In the period post March 31, fund flows appear to be more significantly driven by recent return history in the General Equity and international sectors, judging from the highly significant fund flows appear to be significantly related to returns in General Equity and International sectors. The inference that Japanese investors are herding on the basis of returns can be found in the fact that Bull and Bear fund flows are complementary, and are highly correlated with contemporaneous returns on General Equity and Index accounts (see Brown, Goetzmann, Hiraki, Shiraishi and Watanabe (2002)).
} 
equally divided between foreign equity, domestic fixed income and money market asset classes, although the percentage invested in domestic equities has declined about 10 percent during 2001. On the other hand, there is considerable time variation in the foreign-owned sector asset allocations. Foreign-owned funds were invested about equally in fixed income and equity securities, with about a 10 per cent allocation to Japanese equities in 1998. However, as illustrated in Figure 8, the domestic equity share rose to approximately 50 percent of the total by the end of 1999 , with the allocation remaining stable through the remainder of the period, with a slight decline in domestic equity weighting to the end of the period. In fact, the implied asset allocations of both domestically managed and foreign managed funds appear to be converging over time.

The fact that Japanese aggregate asset allocations appeared to remain relatively constant throughout the period of our study does not necessarily imply consistency in style of management. The broad aggregate asset class allocation may easily obscure changes in allocation within each asset class. For example, Japanese General Equity funds appear to differ significantly from foreign managed funds included within the same ITA classification, with a greater orientation to value stocks. In addition, they were less fully invested in the market over the sample period ${ }^{11}$. To the extent that

\footnotetext{
${ }^{11}$ To analyse the differences between Japanese and foreign General Equity accounts we considered a Sharpe style analysis based on monthly reported Nikko Style Indices, Large Growth, Large Value, Small Equity and MicroCap allowing also for a cash component. The average Sharpe coefficients based on non-overlapping 6 month intervals of the data were quite different for Japanese and foreign General Equity classified funds. While the largest implied weight (Large Growth) was about
} 
BGHOS (2001) identified at least one style of Japanese management to be related to the specific details of the investment trust tax procedures, we would expect changes in style to occur in anticipation of the tax law changes that came into effect on April 1,2000. We examined the asset management style using style benchmarks derived by the GSC procedure described in the previous Section, and by traditional style benchmarks. We find that the asset management styles of Japanese-owned funds were distinctly different from the styles of foreign-owned funds, and that these styles changed over the period of study.

We applied the Brown and Goetzmann algorithm to weekly return data for 3072 funds with at least six weeks of data for the period January 23, 1998 through March 31, 2000, and April 7, 2000 through December 28, 2000. We were able to extract at most five distinct management styles from this data ${ }^{12}$. These styles are quite distinct both in terms of asset allocation and the way in which average allocations change through time. In addition funds tend to group together that have a common fund management ownership and stated fund objective.

the same at 52 percent for both, the foreign funds had a larger average exposure to Small Equity and MicroCap benchmarks (14.71 percent and 13.36 percent respectively, as opposed to 10 percent and 8.09 percent for Japanese funds), and a smaller exposure to value stocks (13.53 percent as opposed to 18.58 percent for Japanese firms). Japanese managed firms were less invested in the market, with an average implied cash position of 10.96 percent as opposed to 6.94 percent for foreign firms.

${ }^{12}$ There is evidence of an additional tax based Limited style in the data prior to the tax law change in March 31, 2000. 
An analysis of this data suggests the following style identifications:

GSC1 Domestic Equity. The average implied Sharpe portfolio weight on TOPIX is 85.6 percent. In terms of ITA classifications, this classification has an average weight by value of 62.3 percent by value in General Equity funds, and 18.8 percent in the Index classification

GSC2 Balanced. With an average Sharpe weighting of 17 percent debt, 36.4 percent TOPIX and 26.7 percent MSCI World Equity (ex Japan), 41 percent by value of these funds are classified as Balanced in the ITA classification

GSC3 International. 79 out of 179 of these funds are classified as International by ITA, and the Sharpe weights average 37.1 percent MSCI ex Japan and 32.7 percent fixed income with a 14.2 percent allocation to the Other category, consistent with a significant diversified international exposure. In addition, foreign firms manage almost twice as much money in this category as do Japanese managers (63.8 percent by value as opposed to 35.8 percent).

GSC4 Index. These funds have an average exposure of 82.6 percent exposure to TOPIX and are passive vehicles, with 29.7 percent by value classified as Index funds and $19.6 \%$ classified as Derivative funds. 
GSC5 Income. Most of these funds have a heavy investment in fixed income investments, with an average Sharpe weighting of only 11.5 percent in TOPIX and MSCI ex Japan equities combined. 16.4 percent of these funds are classified by ITA as "Money Pooled."

In Figure 9 we illustrate the sensitivity of Japanese and foreign owned firms to these style benchmarks. The fund returns are regressed on the five style benchmarks with coefficients constrained to be positive and add to one, allowing for a constant term (alpha), using twelve weeks of data. Not only are the allocations more detailed than in Figures 7 and 8, these style benchmarks account for any non-stationarity caused by market timing, and as explained in BGHOS (2001) account for tax-dilution effects. We now see a clear picture emerging. The high returns of the Japanese managed funds up to March 31, 2000 may be attributed to the fact that many index-type funds (GSC 4) were changing style to active equity management (GSC 1). Subsequent to that date however, many General Equity funds switched back to the more passive style (GSC4) to accommodate the huge inflow of new funds as the TOPIX was falling, accounting for a substantial shortfall in returns.

On the other hand, as illustrated in Figure 10, the relatively poor performance of the foreign owned funds up to March 31, 2000 is partly to be explained by the fact that many of these funds were switching from a broadly based International style (GSC3) in which 
they may have had a comparative advantage into the same narrowly focused domestic Japanese equity style (GSC1) at the same time that Japanese managers were concentrating on this style. Subsequent to March 31, the portfolio allocations have been more stable, with a greater investment in cash and fixed income than the Japanese managers. They were less exposed to the market as the market fell during that period.

A similar picture emerges when we do the analysis again using the more traditional style benchmarks (Figures 11 and 12). In the case of the Japanese funds, the gradual shift from General Equity to Index funds proceeded up to March 31, 2000, with a significant style shift back to the passive Index style in April 2000 with the inflow of new money into this sector. The allocation away from Japanese equity by foreign managed firms subsequent to March 31 is more pronounced in these figures.

In Table 3 we report performance measures for Japanese and foreign investment funds given the two style benchmarks we have used. As noted before, these style benchmarks account for any residual tax dilution effect, and also allow for the possibility that managers adopt dynamic trading strategies that cause expected return and factor exposures to vary through the estimation period. The estimation procedure also allows for the possibility of style shift within each non-overlapping 12-week estimation period. The results show that the high returns for Japanese investment trusts were associated with positive performance in excess of style benchmarks over the 1998-2000 period, 
superior to but not significantly different from foreign manager performance over the same period. Consistent with the performance numbers reported in Figure 6, the positive abnormal performance was concentrated in 1999 through the first quarter of 2000. However, subsequent to that date, Japanese funds experienced significant negative excess returns, amounting to negative 5 percent on an annualized basis. Much of this negative performance occurred in the 12 weeks prior to May 19, 2000, the period of the regulation changes that took place on March 31. In that period Japanese funds experienced an excess return of negative 10 percent on an annualized basis, while foreign funds had a negative excess return of almost 20 percent.

The negative excess returns appear to be associated with major style shifts that occurred subsequently to the major inflow of new money into the investment trust business. Figure 13 shows that the negative weekly excess return measured for the period March 3, 2000 to May 18, 2000 coincided with the large inflow of new funds into Japanese investment trusts of $¥ 15$ Trillion over the prior 12 week period. Across all funds, there was a significant negative relationship between excess returns and prior 12 week net fund inflow into the investment trust sector $(t=-2.12)$. Since the evidence shows clearly that both Japanese and foreign managers changed style significantly over the sample period and are in fact becoming more similar, we should expect some differences in excess return. These differences, such as they are, appear to be associated with the huge inflow of funds into the sector during 2000. 
IV. Conclusion

Japanese investment trusts have underperformed benchmarks in quite a dramatic fashion over the past two decades. This widely publicized fact has shaken public confidence in the industry, the third largest investment trust business in the world outside of the United States and France. It has also opened the door to foreign competition, and foreign-owned funds increased in size more than 70 per cent from new investments in 1998 alone. The perception is obviously that foreign owned funds are more successful than their home-grown competition. If true, this result would be most interesting indeed. In the past, foreign-owned funds specialized in international investments for which they had some comparative advantage. But recently they have been investing more heavily in the Japanese domestic equity market, and are employing large numbers of Japanese managers to construct and monitor these portfolios.

The fact that Japanese investment trusts underperform benchmarks is at best indirect evidence that Japanese funds also underperform their foreign counterparts. In a recent paper BGHOS (2001) show that the underperformance can be attributed almost entirely to the unique tax environment of Japanese investment trusts. In this paper we examine the relative performance issue directly by looking at week by week returns for the period January 23, 1998 through to December 28, 2001. Contrary to popular perception, Japanese managers did not underperform their foreign counterparts over this period of time, and in fact significantly outperformed them in the months leading up to a major 
change in tax regulations at the end of March 2000. Perhaps this indicates that Japanese managers are more skillful. However, the excess return evidence suggests that they happened to be in the right place at the right time, and the negative return subsequent to March 2000 may in part be attributed to the huge inflow of new money into this sector and the style shifts made necessary to accommodate this flow. Thus we attribute the difference in performance to the asset allocation decision, rather than to any different skill in selecting securities. 
References:

Bae, K-H., Ito, K. and Yamada, T. 2001. How do foreigners profit from local investors? Evidence from trades in the Japanese stock market. Unpublished working paper, Hong Kong University of Science and Technology.

Brown, S. J., and Goetzmann, W.N. 1997. Mutual fund styles. Journal of Financial Economics 43 (3): 373-400.

Brown, S. J., Goetzmann, W.N., Hiraki, T., Otsuki,T., and Shiraishi, N. 2001. The Japanese open end mutual fund puzzle. Journal of Business 74(1): 59-78.

Brown, S. J., Goetzmann, W.N., Hiraki, T., Shiraishi, N. and Watanabe, M. 2002. Investor sentiment in Japanese and U.S. daily mutual fund flows, Unpublished working paper, Yale International Center for Finance

(http://papers.ssrn.com/sol3/papers.cfm?abstract_id=302829)

Cai, J., Chan, K. C., and Yamada, T. 1997. The performance of Japanese mutual funds. Review of Financial Studies 10 (2): 237-74.

Ferson, W.E., and Schadt, R.W., 1996, Measuring fund strategy and performance in changing economic conditions. Journal of Finance 51 (2): 425-461

Hsieh, D., and Fung, W. 1997. Empirical characteristics of dynamic trading strategies: The case of hedge funds. Review of Financial Studies 10 (2): 275-302.

Kamesaka, A., Nofsinger, J. and Kawakita, H. 2002. Investment patterns and performance of investor groups in Japan. (Unpublished working paper, Ryukoku University)

Kim, W., 2002. Do foreign investors perform better than locals? Information asymmetry, investor sophistication, and market liquidity (Unpublished working paper, KDI School of Public Policy and Management)

Sharpe, W. F., 1992. Asset allocation: management style and performance measurement. Journal of Portfolio Management (Winter): 7-19. 
Table 1:

Relationship between returns and fund flows to Japanese and foreign managed investment trusts, January 30,1998 to March 31, 2000

\begin{tabular}{|c|c|c|c|c|c|c|c|c|c|c|c|c|c|c|c|}
\hline & \multirow{2}{*}{$\begin{array}{l}\text { Returns } \\
\text { Inter } \\
\text { national }\end{array}$} & \multirow[b]{2}{*}{ Balanced } & \multirow[b]{2}{*}{ Index } & \multirow[b]{2}{*}{$\begin{array}{l}\text { Bull } \\
\text { Funds }\end{array}$} & \multirow[b]{2}{*}{$\begin{array}{l}\text { Bear } \\
\text { Funds }\end{array}$} & \multicolumn{6}{|c|}{ Japan flows } & \multicolumn{3}{|c|}{ Foreign flows } \\
\hline & & & & & & & $\begin{array}{l}\text { General } \\
\text { Equity }\end{array}$ & $\begin{array}{l}\text { Inter } \\
\text { national }\end{array}$ & Balanced & Index & Bull Funds & $\begin{array}{l}\text { Bear } \\
\text { Funds }\end{array}$ & $\begin{array}{l}\text { General } \\
\text { Equity }\end{array}$ & $\begin{array}{l}\text { Inter } \\
\text { national }\end{array}$ & Balanced \\
\hline Returns & General Fouity & $04543 * *$ & $02332 *$ & $08664 * *$ & $08010 * *$ & : $07760 * *$ & 01114 & 00098 & _ $2237 *$ & Q $2440 * *$ & $03185 * *$ & $20 * * !$ & 01056 & $10 *$ & 01583 \\
\hline & General Equity & 0.4345 & 0.2532 & 0.0004 & $0.612 * *$ & -0.1100 & 0.1114 & -0.0998 & -0.2201 & $=0.24+00$ & 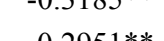 & 0.5850 & 0.1050 & $-0.2019^{\circ}$ & -0.1583 \\
\hline & International & & & & & $-0.4256^{* * *}$ & 0.1185 & -0.0482 & $-0.2717 *$ & -0.2631 & $-0.2951^{* 2}$ & $0.2189^{*}$ & -0.0221 & -0.0725 & $-0.1882^{*}$ \\
\hline & Balanced & & & 0.1785 & $0.1996^{*}$ & -0.1656 & 0.0890 & -0.0420 & -0.0875 & -0.0868 & -0.0289 & 0.0586 & -0.1288 & -0.0078 & -0.1083 \\
\hline & Index & & & & $0.9738^{* *}$ & $-0.9386^{* *}$ & 0.0699 & -0.1382 & $-0.2618^{* *}$ & $-0.2262 *$ & $-0.4517 * *$ & $0.4910 * *$ & 0.0457 & $-0.1947^{*}$ & -0.1335 \\
\hline & Bull Funds & & & & & $-0.9621 * *$ & 0.0677 & -0.1085 & $-0.2397^{*}$ & $-0.2050^{*}$ & $-0.4708 * *$ & $0.5086^{* *}$ & 0.0232 & -0.1604 & -0.1271 \\
\hline & Bear Funds & & & & & & -0.0189 & 0.1245 & $0.2330 *$ & 0.1779 & $0.4375 * *$ & $-0.4890 * *$ & -0.0414 & 0.1559 & 0.1105 \\
\hline $\begin{array}{l}\text { Japan } \\
\text { flows }\end{array}$ & General Equity & & & & & & & 0.0278 & -0.0662 & $-0.2364^{*}$ & -0.0907 & -0.0312 & 0.1743 & -0.0309 & $-0.3404 * *$ \\
\hline & International & & & & & & & & 0.0565 & 0.0542 & $0.2232 *$ & 0.0028 & $-0.2321^{*}$ & $0.4382 * *$ & $0.2589 * *$ \\
\hline & Balanced & & & & & & & & & $0.2937 * *$ & $0.2713^{* *}$ & -0.0691 & -0.1461 & $0.3292 * *$ & $0.3065 * *$ \\
\hline & Index & & & & & & & & & & $0.4567 * *$ & $-0.3399 * *$ & -0.1064 & 0.0648 & $0.2308^{*}$ \\
\hline & Bull Funds & & & & & & & & & & & $-0.5599 * *$ & $-0.2356^{*}$ & $0.2094 *$ & $0.2300 *$ \\
\hline & Bear Funds & & & & & & & & & & & & -0.1233 & -0.0078 & 0.012 \\
\hline $\begin{array}{l}\text { Foreign } \\
\text { flows }\end{array}$ & $\begin{array}{l}\text { General Equity } \\
\text { International }\end{array}$ & & & & & & & & & & & & & $-0.3294 * *$ & $\begin{array}{r}-0.5391 * * \\
0.4236^{* *}\end{array}$ \\
\hline
\end{tabular}

This table reports the correlations between value weighted weekly total returns on ITA investment trust aggregates (augmented by separately accounting for Bull and Bear funds), and fund flows into Japanese and foreign managed open type investment trusts. These fund flows are defined as the total assets reported at week end within each fund aggregate less the total assets reported as of the previous week augmented by the value weighted total return during the week. Single asterisks denote significance at the 5 percent level, and double asterisks denote significance at the one percent level. 
Table 2:

Relationship between returns and fund flows to Japanese and foreign managed investment trusts, April 7, 2000 to December 28, 2001

\begin{tabular}{|c|c|c|c|c|c|c|c|c|c|c|c|c|c|c|c|}
\hline & & \multicolumn{5}{|l|}{ Returns } & \multicolumn{6}{|c|}{ Japan flows } & \multicolumn{3}{|c|}{ Foreign flows } \\
\hline & & $\begin{array}{l}\text { Inter } \\
\text { national }\end{array}$ & Balanced & Index & $\begin{array}{l}\text { Bull } \\
\text { Funds }\end{array}$ & $\begin{array}{l}\text { Bear } \\
\text { Funds }\end{array}$ & $\begin{array}{l}\text { General } \\
\text { Equity }\end{array}$ & $\begin{array}{l}\text { Inter } \\
\text { national }\end{array}$ & Balanced & Index & Bull Funds & $\begin{array}{l}\text { Bear } \\
\text { Funds }\end{array}$ & $\begin{array}{l}\text { General } \\
\text { Equity }\end{array}$ & $\begin{array}{l}\text { Inter } \\
\text { national }\end{array}$ & Balanced \\
\hline Returns & General Equity & $0.7464 * *$ & $0.3397 * *$ & $0.8968 * *$ & $0.8364 * *$ & $-0.7638 * *$ & $0.3886 * *$ & $0.3237 * *$ & -0.0832 & 0.0114 & -0.0653 & $0.4639 * *$ & $0.6197 * *$ & $0.3218 * *$ & -0.0216 \\
\hline & International & & $0.5481 * *$ & $0.6286^{* *}$ & $0.5964 * *$ & $-0.6240 * *$ & 0.0874 & $0.4914^{* *}$ & 0.0742 & -0.0887 & -0.0136 & $0.3987 * *$ & $0.3082 * *$ & $0.4443 * *$ & -0.0972 \\
\hline & Balanced & & & $0.4222 * *$ & $0.4177 * *$ & $-0.3576^{* *}$ & $0.2789 * *$ & $0.2611 *$ & 0.1260 & -0.0324 & $0.2661^{*}$ & 0.0422 & 0.1806 & $0.3593 * *$ & -0.0808 \\
\hline & Index & & & & $0.9705 * *$ & $-0.8640 * *$ & $0.4412 * *$ & $0.2656^{*}$ & -0.1029 & -0.0359 & -0.0100 & $0.4311 * *$ & $0.4893 * *$ & $=0.2953^{* *}$ & -0.0111 \\
\hline & Bull Funds & & & & & $-0.9065^{* *}$ & $0.3683 * *$ & $0.2464 *$ & -0.1038 & -0.0518 & -0.0059 & $0.4235^{* *}$ & $0.3956^{* *}$ & $=0.3043 * *$ & 0.0230 \\
\hline & Bear Funds & & & & & & $-0.2645^{*}$ & $-0.2668^{*}$ & 0.0469 & 0.1123 & 0.1115 & $-0.4092 * *$ & $-0.2901 * *$ & $-0.3746 * *$ & 0.0343 \\
\hline $\begin{array}{l}\text { Japan } \\
\text { flows }\end{array}$ & General Equity & & & & & & & -0.0703 & $-0.2357 *$ & 0.2045 & $0.2122 *$ & -0.0523 & $0.5562 * *$ & $=\quad-0.1474$ & 0.0713 \\
\hline & International & & & & & & & & -0.0017 & -0.1573 & -0.0003 & $0.2625^{*}$ & 0.0312 & 0.1700 & -0.0360 \\
\hline & Balanced & & & & & & & & & 0.0163 & $-0.2299 *$ & 0.0634 & -0.0878 & $0.4658 * *$ & 0.0484 \\
\hline & Index & & & & & & & & & & $0.3478 * *$ & $-0.2597 *$ & $0.2111^{*}$ & -0.1777 & 0.0574 \\
\hline & Bull Funds & & & & & & & & & & & $-0.5395 * *$ & 0.1098 & -0.1845 & 0.0294 \\
\hline & Bear Funds & & & & & & & & & & & & 0.0538 & $0.2083^{*}$ & 0.0712 \\
\hline $\begin{array}{l}\text { Foreign } \\
\text { flows }\end{array}$ & $\begin{array}{l}\text { General Equity } \\
\text { International }\end{array}$ & & & & & & & & & & & & & 0.1386 & $\begin{array}{c}0.0667 \\
0.2145^{*}\end{array}$ \\
\hline
\end{tabular}

This table reports the correlations between value weighted weekly total returns on ITA investment trust aggregates (augmented by separately accounting for Bull and Bear funds), and fund flows into Japanese and foreign managed open type investment trusts. These fund flows are defined as the total assets reported at week end within each fund aggregate less the total assets reported as of the previous week augmented by the value weighted total return during the week. Single asterisks denote significance at the 5 percent level, and double asterisks denote significance at the one percent level. 
Table 3: Performance measures for Japanese and foreign owned funds 1998-2001

\begin{tabular}{|c|c|c|c|c|c|c|c|}
\hline & \multicolumn{3}{|c|}{ Five GSC Style benchmarks } & & \multicolumn{3}{|c|}{11 Augmented ITA style benchmarks } \\
\hline $\begin{array}{r}12 \text { week } \\
\text { period ending }\end{array}$ & $\begin{array}{r}\text { Japanese } \\
\text { Funds } \\
\end{array}$ & Foreign Funds & Difference & $\begin{array}{r}12 \text { week } \\
\text { period ending }\end{array}$ & $\begin{array}{r}\text { Japanese } \\
\text { Funds } \\
\end{array}$ & Foreign Funds & Difference \\
\hline 24-Apr-98 & $-0.00 \%$ & $0.07 \%$ & $-0.08 \%$ & 24-Apr-98 & $0.04 \%$ & $0.20 \%$ & $-0.17 \%$ \\
\hline 17-Jul-98 & $0.01 \%$ & $-0.10 \%$ & $0.11 \%$ & 17-Jul-98 & $0.01 \%$ & $0.09 \%$ & $-0.08 \%$ \\
\hline 9-Oct-98 & $-0.22 \%$ & $-0.09 \%$ & $-0.13 \%$ & 9-Oct-98 & $-0.14 \%$ & $-0.31 \%$ & $0.18 \%$ \\
\hline 1-Jan-99 & $0.10 \%$ & $0.03 \%$ & $0.07 \%$ & 1-Jan-99 & $0.05 \%$ & $0.04 \%$ & $0.02 \%$ \\
\hline 26-Mar-99 & $0.08 \%$ & $-0.03 \%$ & $0.11 \%$ & 26-Mar-99 & $0.04 \%$ & $-0.04 \%$ & $0.08 \%$ \\
\hline 18-Jun-99 & $0.06 \%$ & $0.02 \%$ & $0.05 \%$ & 18-Jun-99 & $0.05 \%$ & $-0.11 \%$ & $0.16 \%$ \\
\hline 10-Sep-99 & $0.11 \%$ & $0.04 \%$ & $0.07 \%$ & 10-Sep-99 & $0.04 \%$ & $-0.07 \%$ & $0.12 \%$ \\
\hline 3-Dec-99 & $0.07 \%$ & $0.01 \%$ & $0.06 \%$ & 3-Dec-99 & $0.08 \%$ & $-0.05 \%$ & $0.13 \%$ \\
\hline $25-F e b-00$ & $0.09 \%$ & $0.09 \%$ & $0.00 \%$ & $25-F e b-00$ & $0.17 \%$ & $0.15 \%$ & $0.02 \%$ \\
\hline 19-Мay-00 & $-0.20 \%$ & $-0.38 \%$ & $0.18 \%$ & 19-May-00 & $-0.06 \%$ & $-0.42 \%$ & $0.36 \%$ \\
\hline 11-Aug-00 & $-0.04 \%$ & $0.06 \%$ & $-0.10 \%$ & 11-Aug-00 & $-0.04 \%$ & $0.07 \%$ & $-0.11 \%$ \\
\hline 3-Nov-00 & $-0.00 \%$ & $-0.05 \%$ & $0.05 \%$ & 3-Nov-00 & $0.06 \%$ & $-0.04 \%$ & $0.10 \%$ \\
\hline 26-Jan-01 & $-0.13 \%$ & $-0.05 \%$ & $-0.08 \%$ & 26-Jan-01 & $-0.10 \%$ & $0.06 \%$ & $-0.16 \%$ \\
\hline 20-Apr-01 & $-0.23 \%$ & $-0.03 \%$ & $-0.20 \%$ & 20-Apr-01 & $-0.32 \%$ & $-0.03 \%$ & $-0.29 \%$ \\
\hline 13-Jul-01 & $-0.09 \%$ & $-0.03 \%$ & $-0.06 \%$ & 13-Jul-01 & $0.04 \%$ & $0.05 \%$ & $-0.01 \%$ \\
\hline $5-O c t-01$ & $-0.07 \%$ & $0.04 \%$ & $-0.10 \%$ & 5-Oct-01 & $-0.02 \%$ & $0.14 \%$ & $-0.16 \%$ \\
\hline 28-Dec-01 & $-0.01 \%$ & $0.11 \%$ & $-0.13 \%$ & 28-Dec-01 & $0.03 \%$ & $0.16 \%$ & $-0.13 \%$ \\
\hline $\begin{array}{r}24-A p r-98 \text { to } \\
25-F e b-00\end{array}$ & $\begin{array}{l}0.03 \% \\
(0.95)\end{array}$ & $\begin{array}{r}0.00 \% \\
(0.15)\end{array}$ & $\begin{array}{r}0.03 \% \\
(1.05)\end{array}$ & $\begin{array}{r}24-A p r-98 \text { to } \\
25-F e b-00\end{array}$ & $\begin{array}{l}0.04 \% \\
(1.46)\end{array}$ & $\begin{array}{r}-0.01 \% \\
(-0.22)\end{array}$ & $\begin{array}{r}0.05 \% \\
(1.31)\end{array}$ \\
\hline $\begin{array}{l}\text { 19-May-00 to } \\
28-\text { Dec-01 }\end{array}$ & $\begin{array}{l}-0.10 \% \\
(-3.23)\end{array}$ & $\begin{array}{r}-0.04 \% \\
(-0.79)\end{array}$ & $\begin{array}{r}-0.05 \% \\
(-1.29)\end{array}$ & $\begin{array}{l}\text { 19-May-00 to } \\
\text { 28-Dec-01 }\end{array}$ & $\begin{array}{r}-0.05 \% \\
(-1.16)\end{array}$ & $\begin{array}{r}-0.00 \% \\
(-0.02)\end{array}$ & $\begin{array}{r}-0.05 \% \\
(-0.68)\end{array}$ \\
\hline $\begin{array}{r}24-A p r-98 \text { to } \\
28-D e c-01\end{array}$ & $\begin{array}{c}-0.03 \% \\
(-1.01)\end{array}$ & $\begin{array}{c}-0.02 \% \\
(-0.65)\end{array}$ & $\begin{array}{r}-0.01 \% \\
(-0.39)\end{array}$ & $\begin{array}{r}24-A p r-98 \text { to } \\
28-D e c-01\end{array}$ & $\begin{array}{r}-0.00 \% \\
(-0.12)\end{array}$ & $\begin{array}{r}-0.01 \% \\
(-0.17)\end{array}$ & $\begin{array}{r}0.00 \% \\
(0.09)\end{array}$ \\
\hline
\end{tabular}

Numbers in this table give the weighted average of alpha measured in units of weekly returns for all funds in each ownership category, where the weights are proportional to the total assets under management in each fund estimated for each of 17 non-overlapping 12 week periods 1998-2000. The individual fund alphas are estimated from the

regression equation $R_{j t}=\alpha_{j}+\Sigma \beta_{J j} \hat{\mu}_{J t}+\varepsilon_{j t}$ where the coefficients $\beta_{J j}$ are constrained to

be positive and to sum to one, and the factors $\hat{\mu}_{J t}$ are the style benchmarks given in the first panel by the 5 GSC style benchmarks and in the second panel by the 11 augmented ITA style categories. Note that if the fund's style is constant over the 12 week estimation period ending in the last date given left hand column, the factor loadings $\beta_{J j}$ are equal to one where fund $j$ belongs to style $\mathrm{J}$ and are zero otherwise. This constrained regression therefore allows for the possibility of style shift over the estimation period. 
Assets under Management

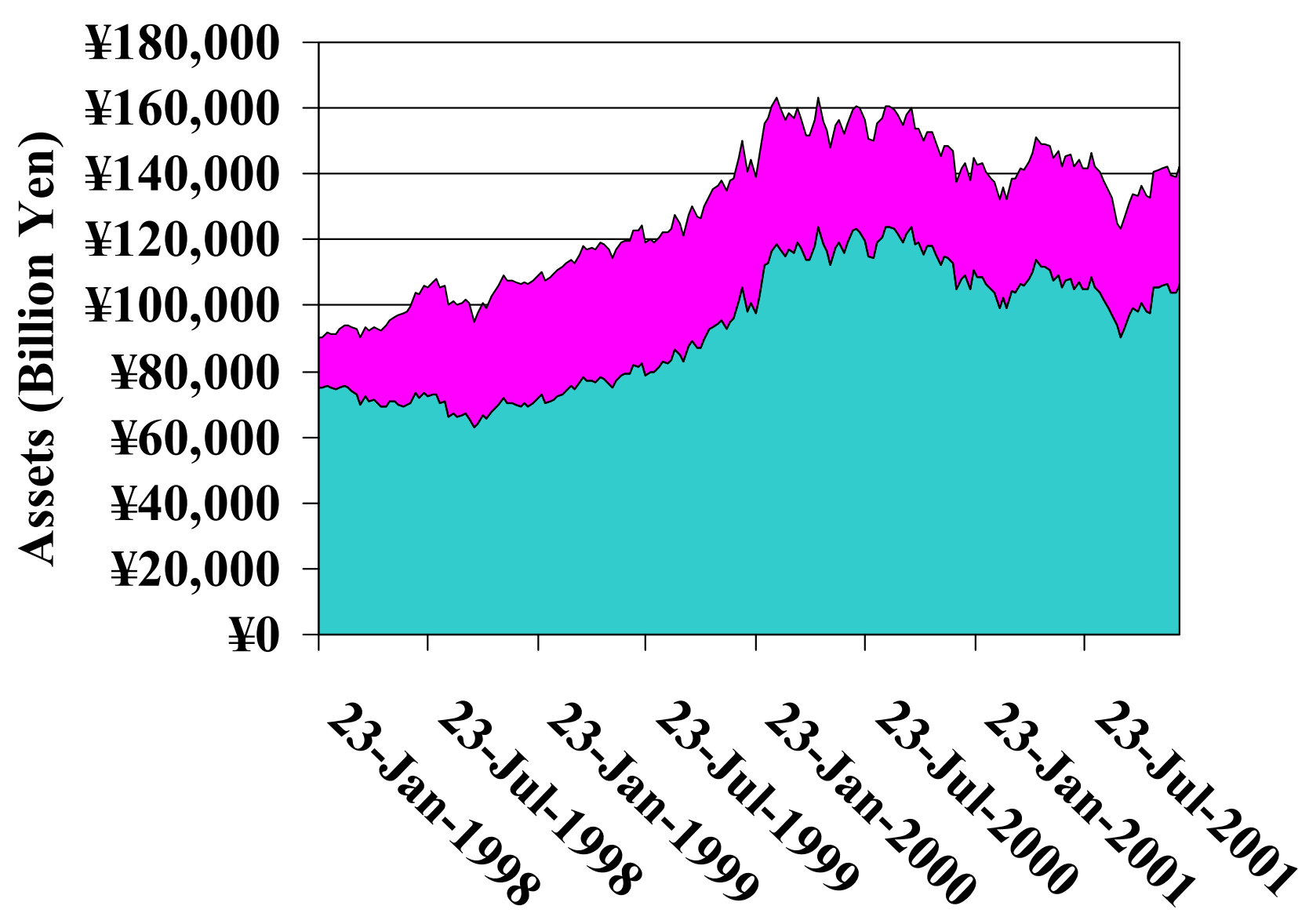

$\square$ Foreign $\square$ Japan 
Figure 2

\section{Assets under management by management firm, January 23, 1998}

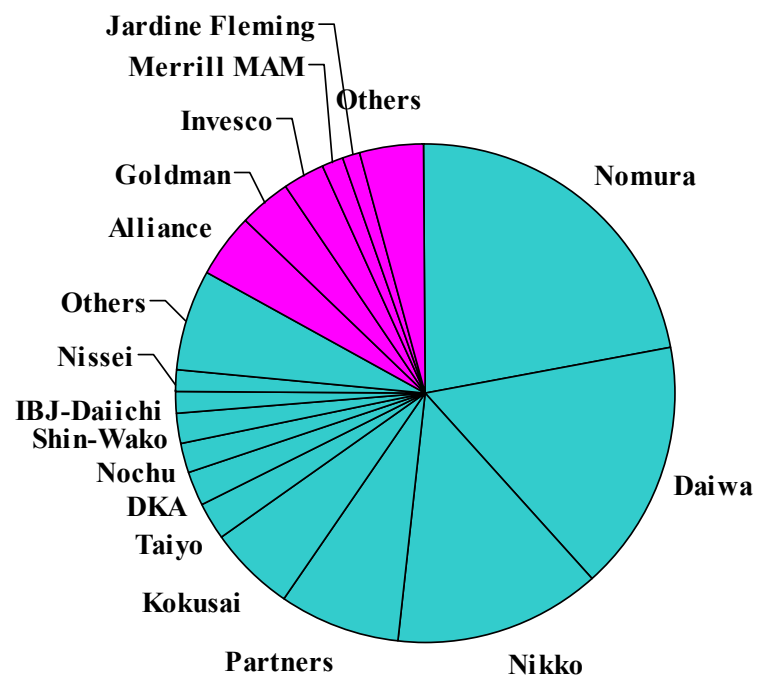

This Figure gives the breakdown of assets under management by management company as of January 23,1998 . At that point, total assets under management amounted to ¥¥00.17 Trillion. The “Other” category includes all management firms with less than ¥¥1 Trillion under management. The “Other” category of Japanese firms managed $¥ 6.00$ Trillion, and includes (in order of assets under management) management firms Nihon, Sumisei-G, Fuji, Cosmo, Daido-L, Tokyo-Mitsubishi, Sakura, Tokai, Daiwa-Sumigin and Universal. The "Other" category of foreign firms managed $¥ 3.74$ Trillion, and includes (in order of assets under management) management firms Morgan Stanley, Fidelity, Deutsche M.G., Schroders, Gurtmore, AIMIC, Barings, Credit Suisse, Rothschild and Maple. 
Figure 3

\section{Assets under management by management firm,}

May 2, 2000

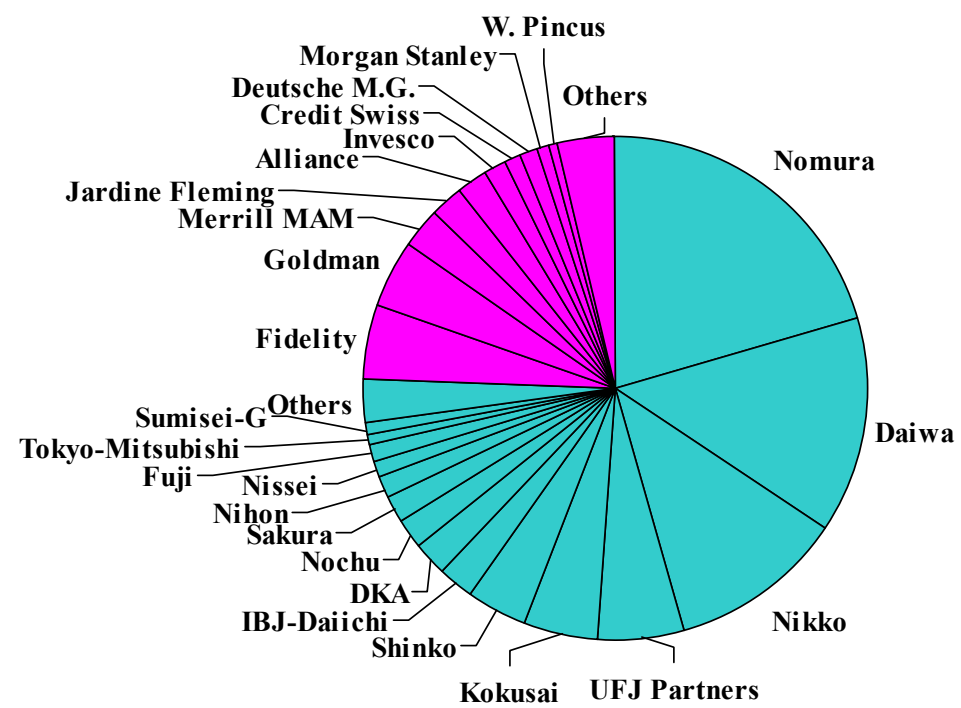

This Figure gives the breakdown of assets under management by management company as of May 2, 2000. At that point, total assets under management amounted to $¥ 138.93$ Trillion. The “Other” category includes all management firms with less than ¥ $¥ 1$ Trillion under management. The “Other” category of Japanese firms managed ¥¥4.28 Trillion, and includes (in order of assets under management) management firms Daiwa-Sumigin, Daido-L, Asahi-Tokyo, Semisei-G, Sumishin A.M., Asahi Life, Yasuda-Kasai G., Cosmo, Mitsui Marine A.M., Sanyo, Mitsui Life G, Tokio Marine, Meiji-Dresdner, Mitsubishi Trust, Shinkin and Sawakami. The "Other" category of foreign firms managed $¥ 5.83$ Trillion, and includes (in order of assets under management) management firms Rothschild, Schroders, Pictet, SSB City, Frank Russell, AIMIC, JM Morgan Flemming, GE, Gurtmore, Baring, SG Yamaichi, Commerz, UBS, AIG, Scudder, C. Lyonnais, BNP Paribas, ABN AMRO, HSBC, MFS, State Street, ING, INDOCOM, Prudential-Mitsui, Yasuda PaineWebber (the latter two classified as joint Japanese foreign ownership). Note that UFJ Partners includes Partners, Universal and Tokai, and Shinko includes Shin-Wako and Taiyo. 
Figure 4

\section{Assets under management by management firm, December 28, 2001}

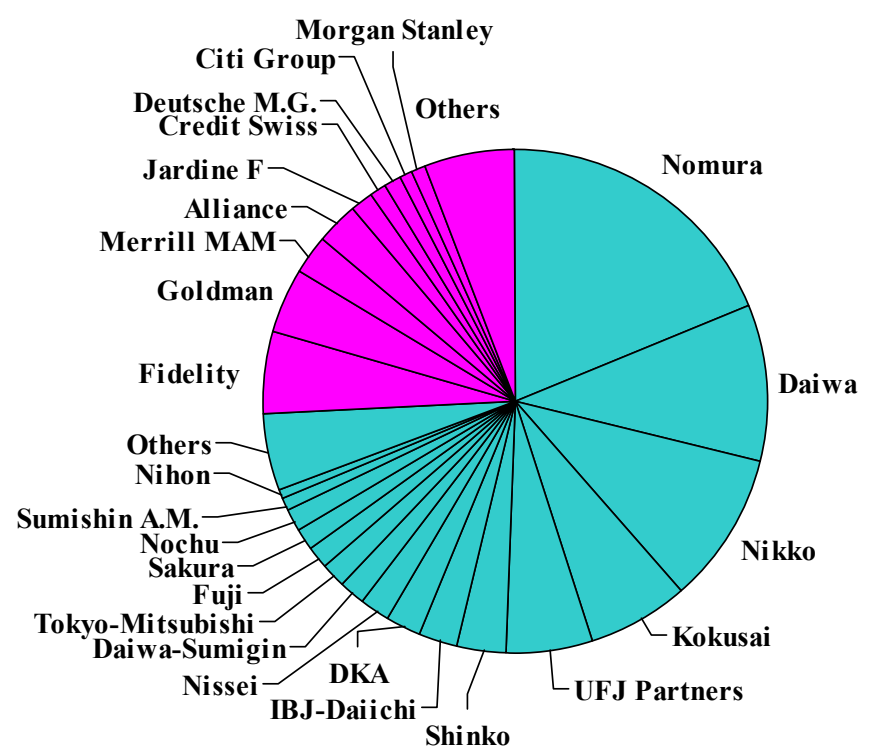

This Figure gives the breakdown of assets under management by management company as of December 28, 2001. At that point, total assets under management amounted to ¥113.41 Trillion. The “Other” category includes all management firms with less than ¥¥1 Trillion under management. The "Other” category of Japanese firms managed ¥¥7.26 Trillion, and includes (in order of assets under management) management firms Mitsubishi Trust, Sumisei-G, Asahi-Tokyo, Chuo-Mitsui AM, Daido-L, Sumitomo Life, Semisei-G, Asahi Life, Shinkin, Yasuda-Kasai G., Sawakami, Mitsu-Sumitomo Marine A.M, Tokio Marine, Meiji-Dresdner, Mitsui Life G, Sparx, Cosmo, Mitsui Marine A.M., Sanyo and Hitachi. The “Other” category of foreign firms managed ¥¥.14 Trillion, and includes (in order of assets under management) management firms Invesco, Schroders, Rothschild, W. Pincus, Pictet, Frank Russell, BNP Paribas, Scudder, Barclays, SG Yamaichi, SSB City, AIMIC, United AM, Gurtmore, Prudential, Franklin Templeton, JM Morgan Flemming, GE, Credit Agricol, Baring, UBS, State Street, Commerz, AIG, ING, Mellon, HSBC, MFS, PCA, C. Lyonnais, ABN AMRO, Credit Lyonnais, INDOCOM, Yasuda PaineWebber and Prudential-Mitsui (the latter two classified as joint Japanese foreign ownership). Note that UFJ Partners includes Partners, Universal and Tokai, and Shinko includes Shin-Wako and Taiyo. 
Figure 5:

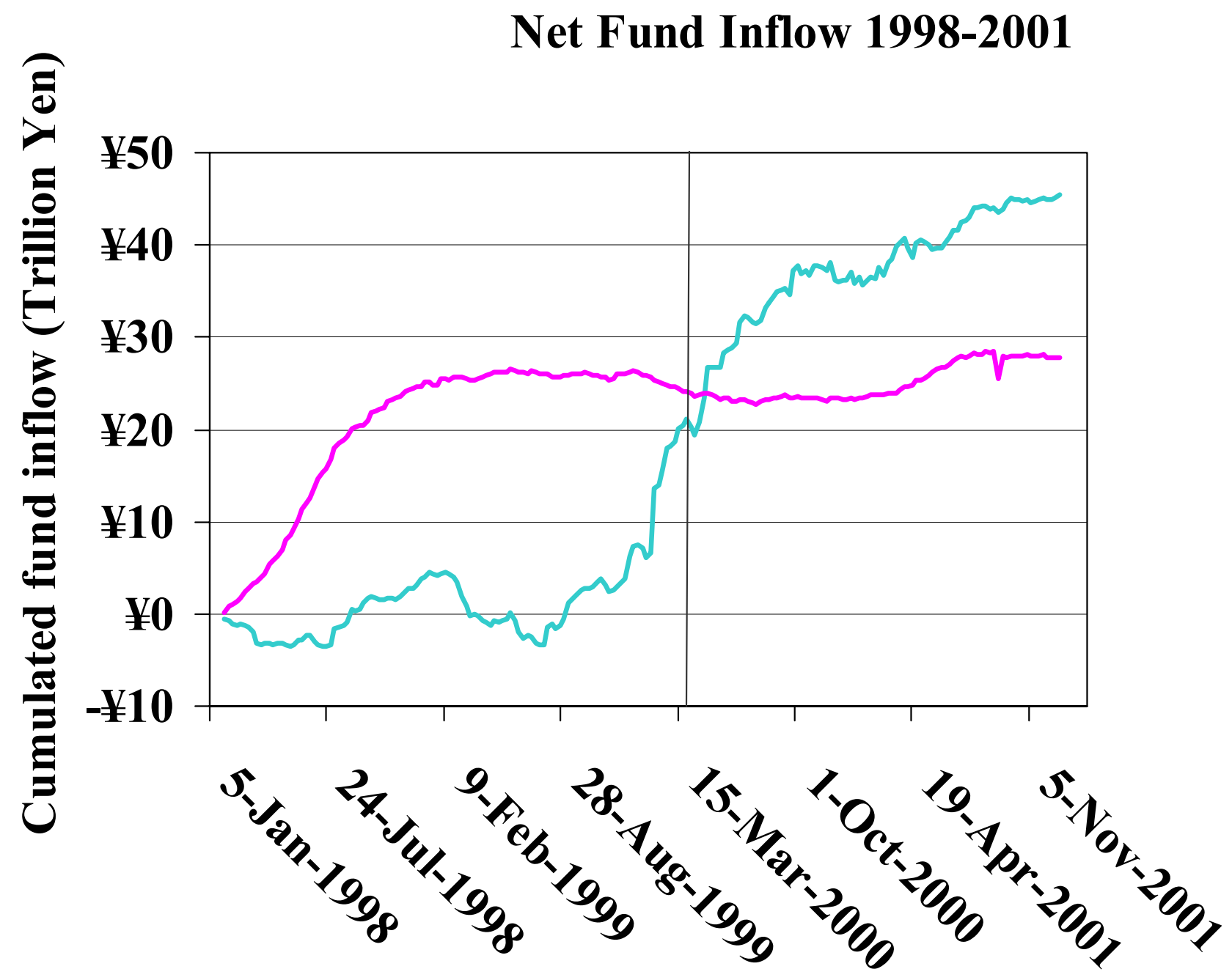

- Japan

- Foreign

- 31-Mar

28 
Figure 6:

Investment Performance of Japanese and foreign firms

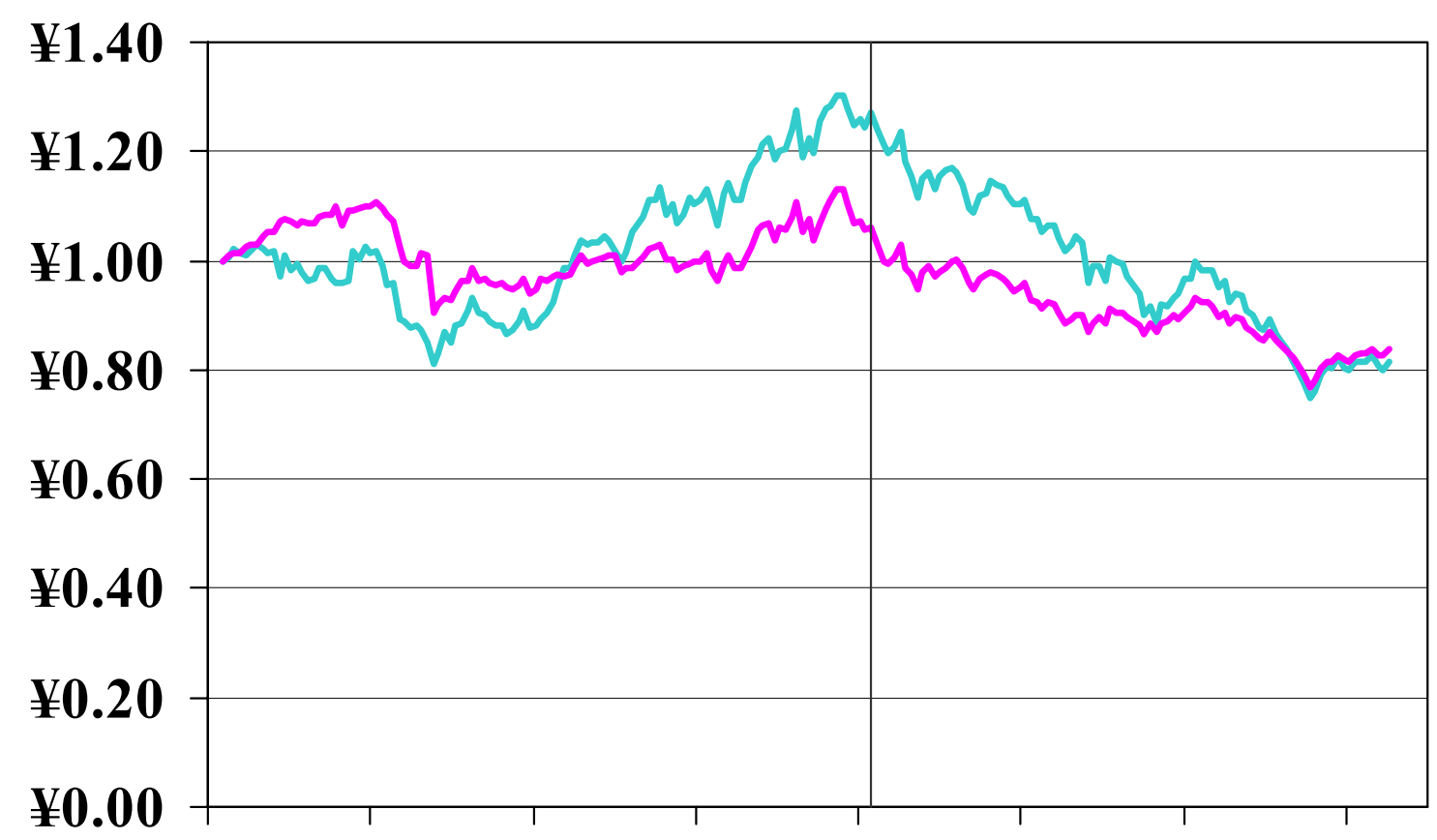

Japan

- Foreign

- 31-Mar-00

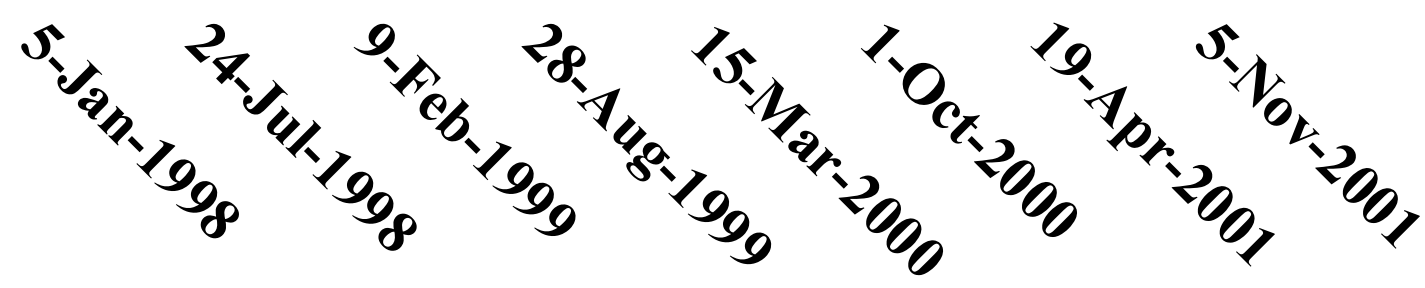

29 
Implied Asset Allocation by Japanese firms

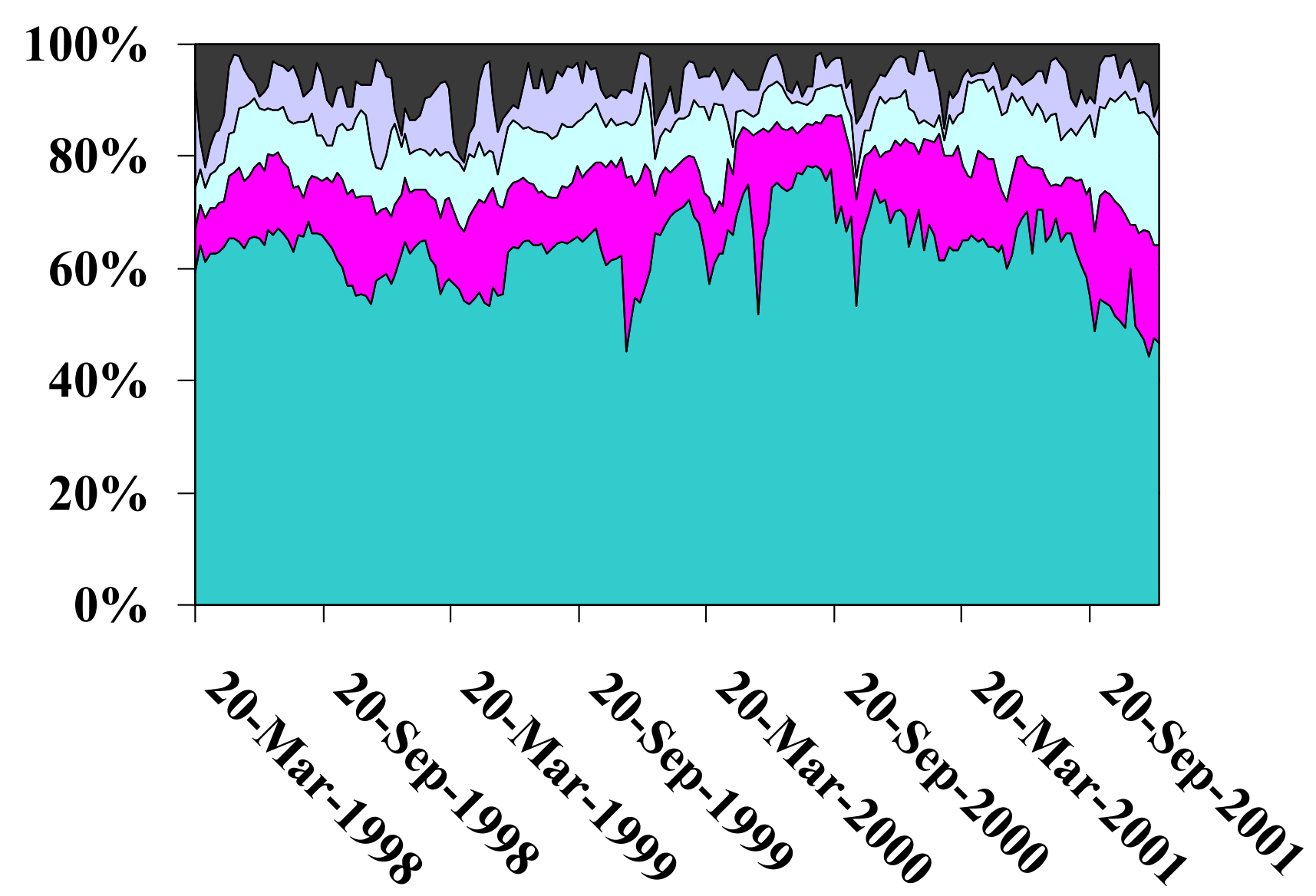

$\square$ Other

$\square$ CD

$\square$ Bond

$\square$ MSCI

$\square$ Topix 
Figure 8:

Implied Asset Allocation by Foreign Firms

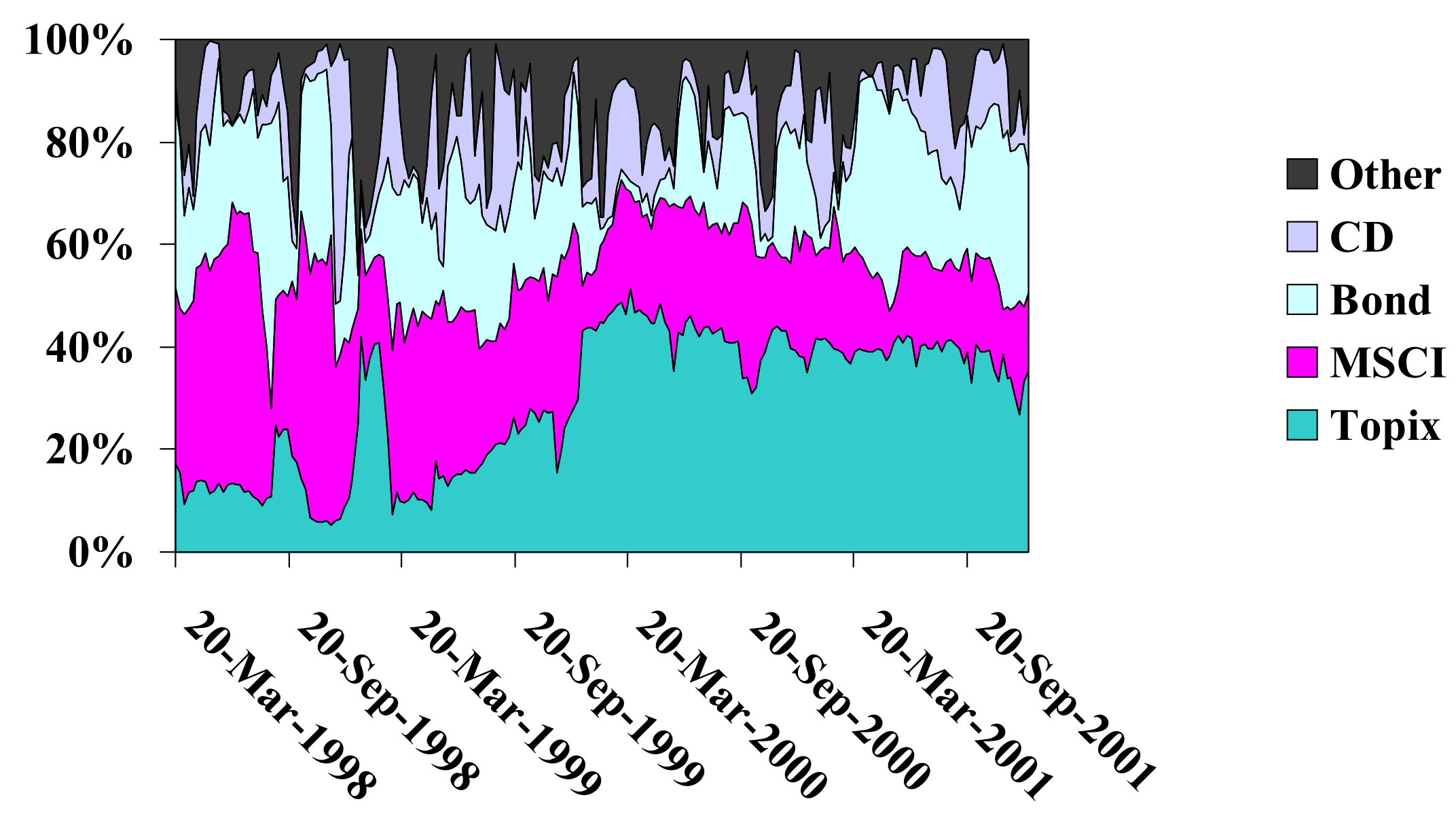




\section{Figure 9:}

Japanese funds by GSC styles

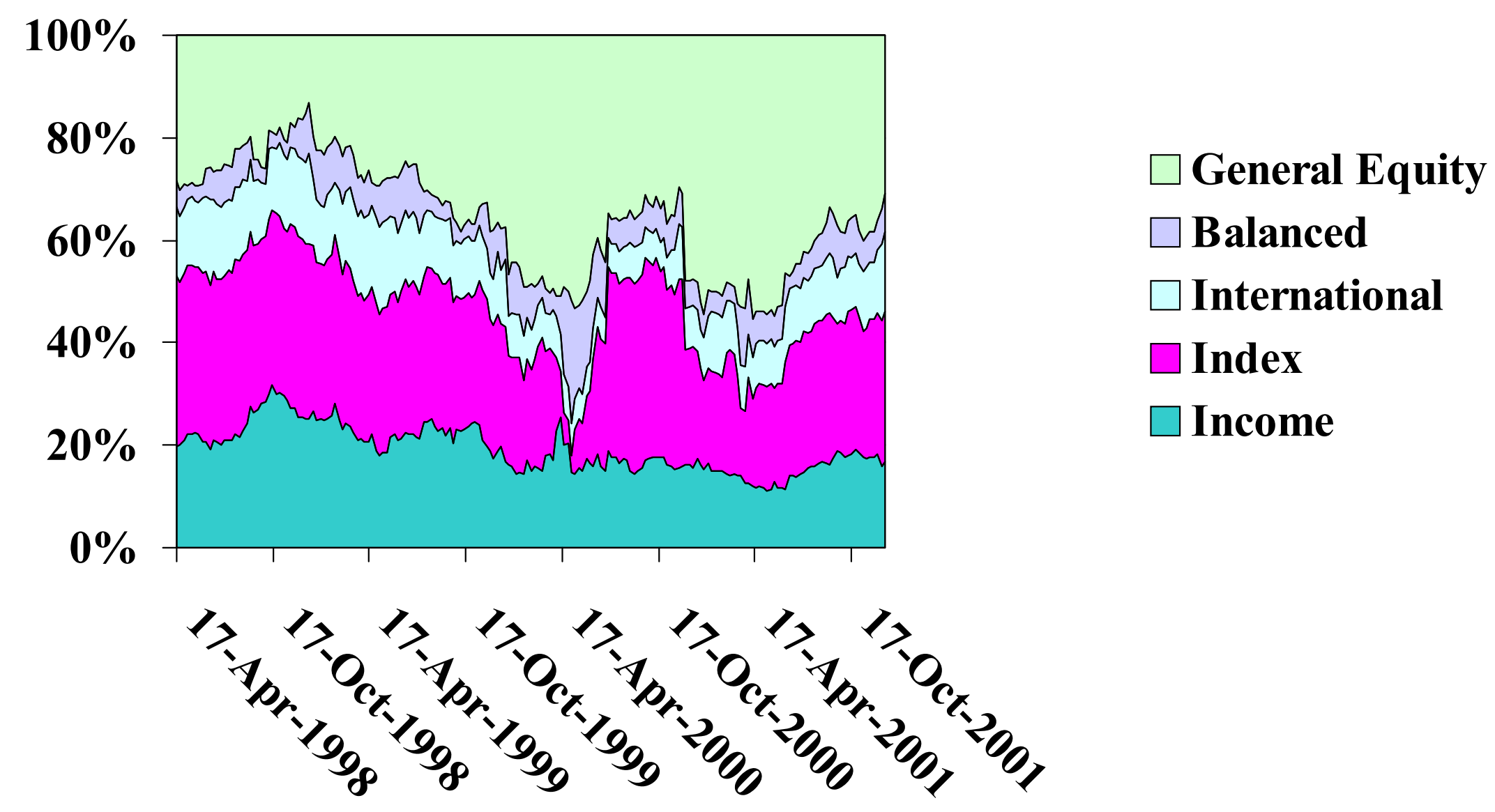




\section{Figure 10:}

Foreign funds by GSC styles

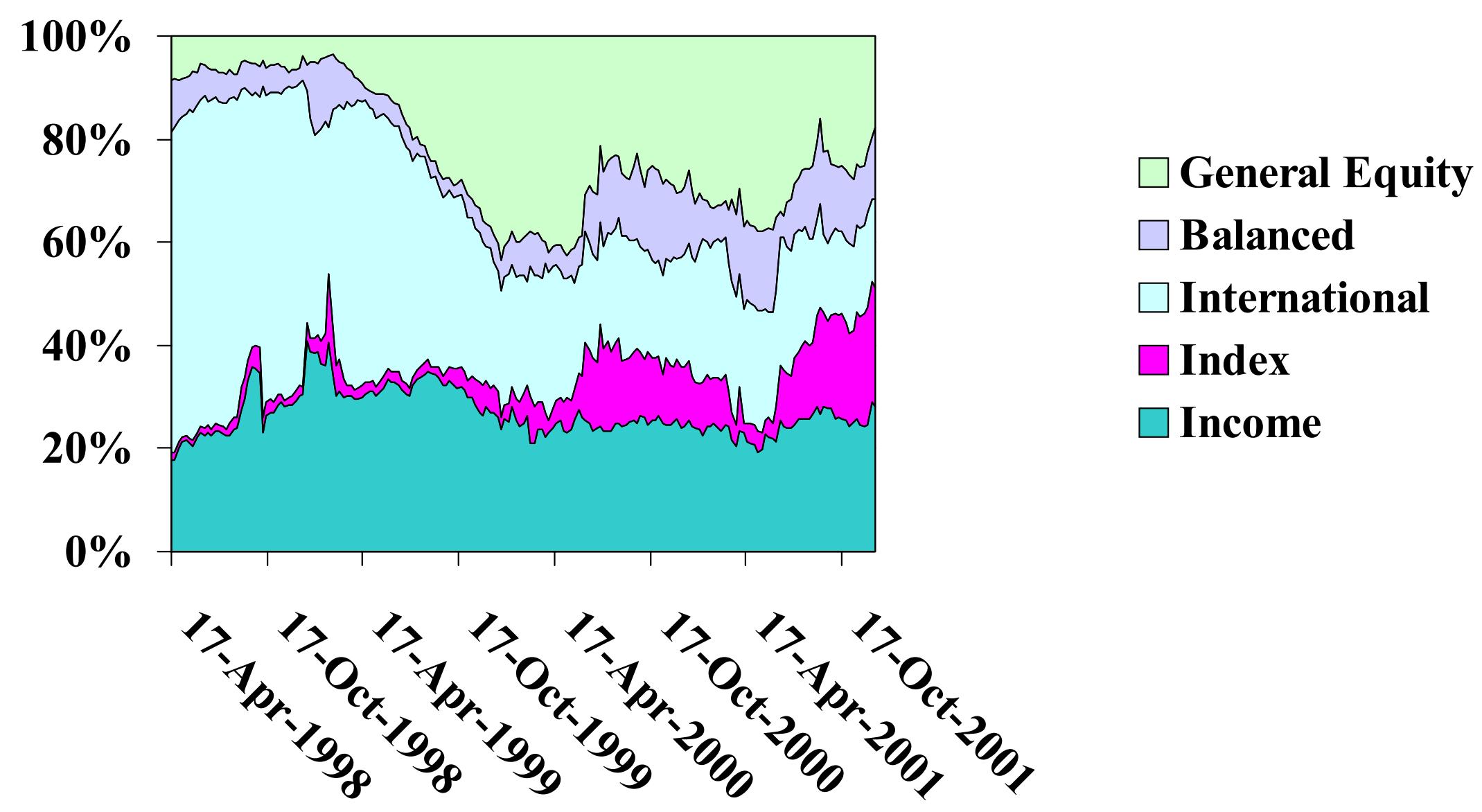


Figure 11:

Japanese funds and augmented ITA style benchmarks

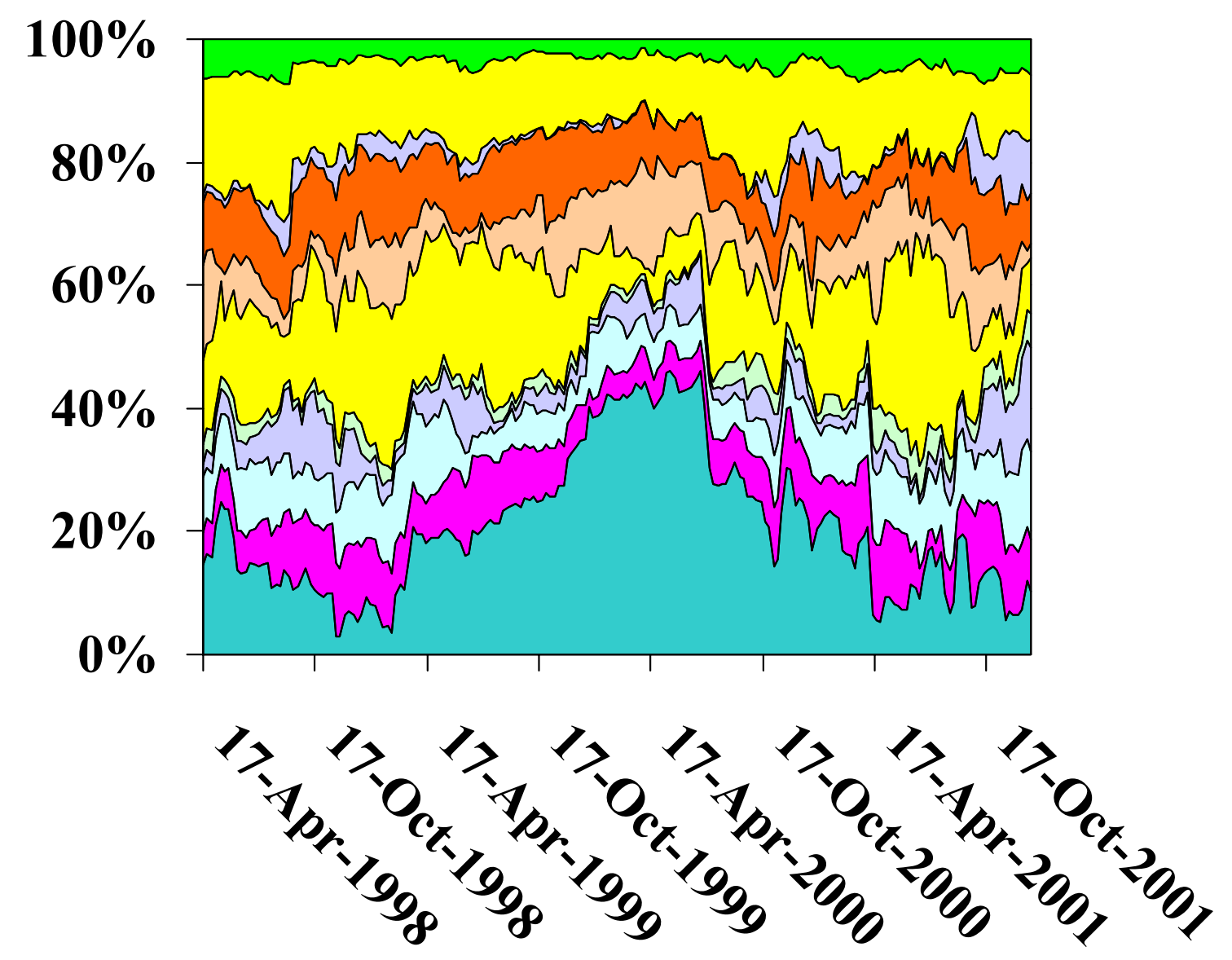

$\square$ Bear Funds

$\square$ Bull Funds

$\square$ Derivatives

$\square$ Money Pool

$\square$ Industry Index

$\square$ Index

$\square$ CB

$\square$ Limited

$\square$ Balanced

$\square$ International

$\square$ General Equity 
Foreign funds and augmented ITA benchmarks

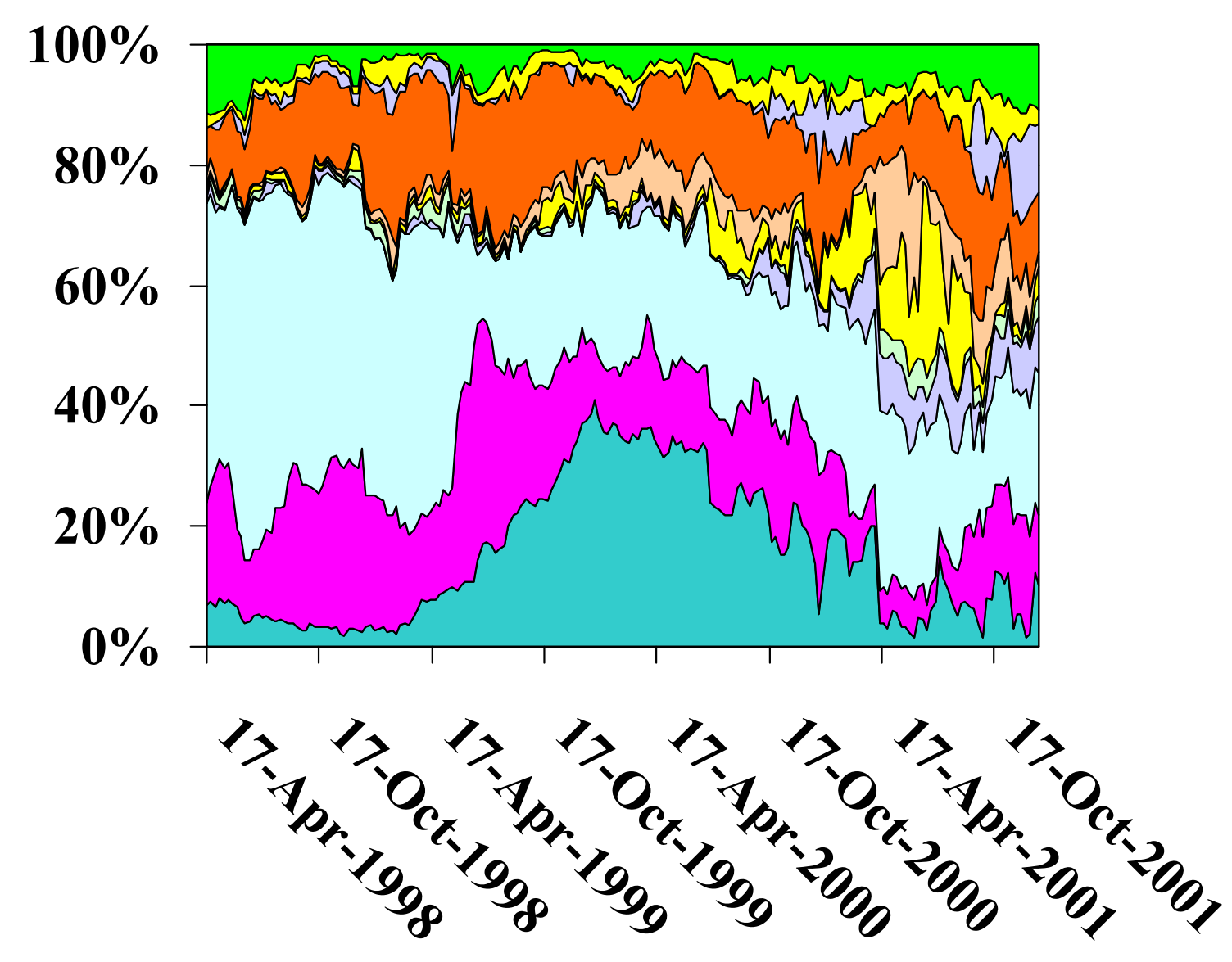

$\square$ Bear Funds

$\square$ Bull Funds

$\square$ Derivatives

$\square$ Money Pool

$\square$ Industry Index

$\square$ Index

$\square \mathbf{C B}$

$\square$ Limited

$\square$ Balanced

$\square$ International

$\square$ General Equity 
Figure 13:

Japanese excess returns and prior fund flow

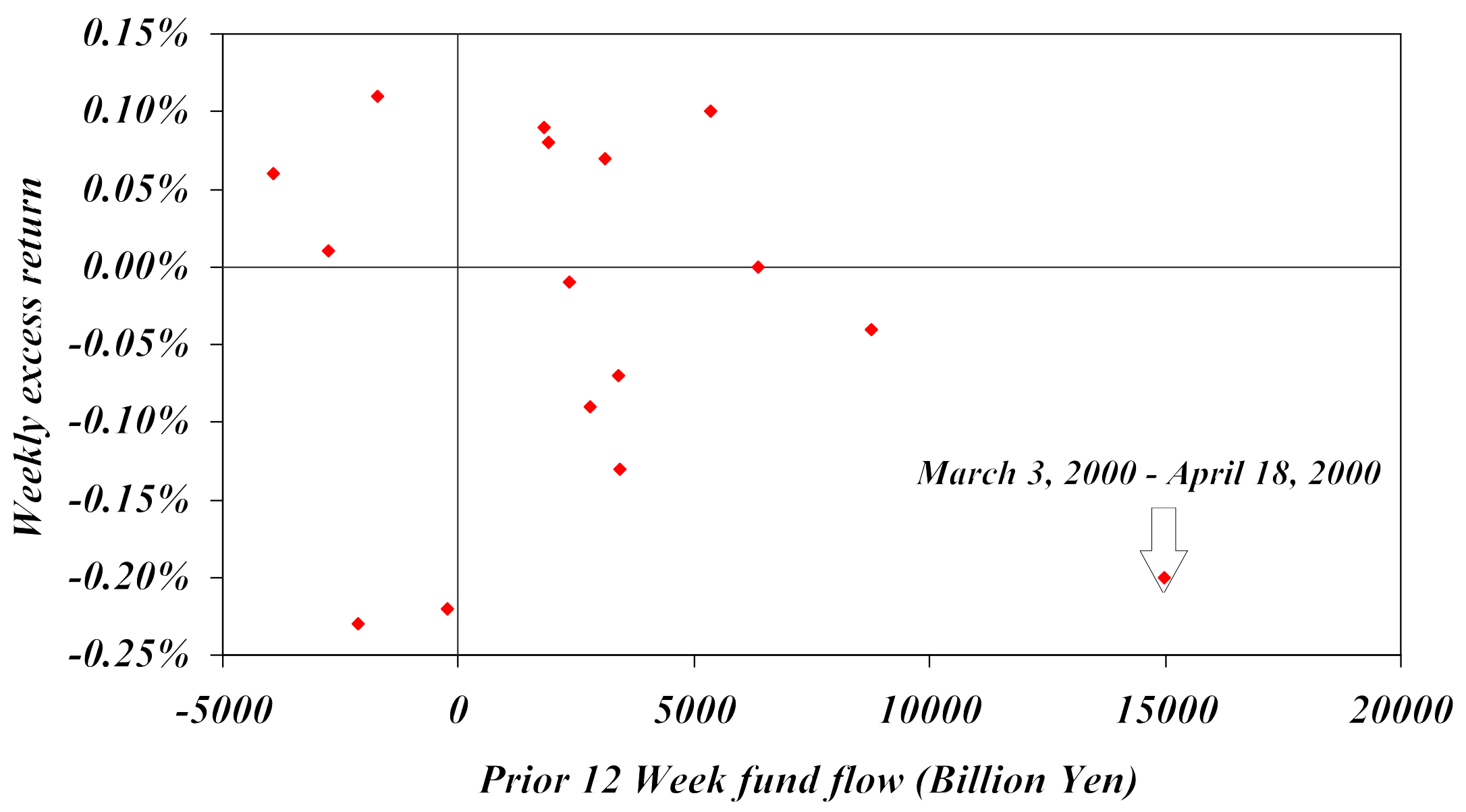


